\title{
4.3 \\ GENRES OF CONSPIRACY IN NINETEENTH-CENTURY BRITISH WRITING
}

\author{
Ben Carver
}

\section{Introduction}

In Dan Brown's Robert Langdon series, the pretext of the narrative action (of detection and pursuit) is the existence of secret societies that have persisted through history along a timeline that connects the twenty-first century literature to the European Renaissance and begins much earlier. To understand the possibility of a novel of this kind, which engages a modern historiandetective to demystify ancient conspiracy, requires an explanation of the scientific, print and political culture of the nineteenth century, whose narrative formations enabled the transmission of stories that articulated infiltration, detection and anxiety.

Genres that remain familiar to us today were established in the Europe in the nineteenth century: Detective, espionage and invasion stories and novels. The national focus of this chapter is on British literature and how the threat of conspiracy, imagined in popular fiction, depended on an idea of nationhood that was opposed by plots that threatened it from beyond its borders or by enemies at home, who served other interests and political programmes. Likewise, while conspiracy fiction evolved in relation to genres of popular fiction with distinct narrative features, the allure of conspiracy as a literary formula lay also in its mobility - the fact that it might not be restricted to the generic conventions within whose bounds it acquired intelligible and marketable narrative form. The transmission of conspiracy narratives required a developed and orderly system of print publication, whose success depended on recognition of these narrative conventions in their niches of the popular press. Arthur Conan Doyle's Sherlock stories could be found in the Strand for instance; if the reader was interested in future-oriented romances of the technological imagination, she might turn to Pearson's Weekly (among others). Narratives of conspiracy needed, however, to suggest the possibility of infiltration into and out of these literary enclaves, between life and fiction. Conspiracy was a creeping danger that could permeate the political order at large just as it did this well-regulated print environment. The conspiracist imagination involved engaging - even if in the modes of generic fiction - the frisson of social paranoia.

This necessarily brief overview identifies the tropes and generic conventions in nineteenthcentury fiction that gave rise to what can now be glossed as 'conspiracy fiction' - a retrospective term. Several of the figures that have entered the lexicon of conspiracy culture depended on technological conditions and political ideas of their time, for instance the political anarchist 
armed with dynamite operating in newly built sewage tunnels. The emplotment of the figure of conspiracy in narrative form, however, established literary tropes that persisted in conspiracy fiction much later. Thomas Pynchon's The Crying of Lot 49 (1966) was not the first narrative to conflate conspiracies with postal networks and enemies conspiring to invade. It inherited motifs from late nineteenth-century British invasion fiction. Ironic, self-aware conspiracy theories are not new either: About 200 years ago, Richard Whately claimed that Napoleon was an entirely fictitious character and that Moscow had never burned down.

To attempt a list of nineteenth-century conspiracy fiction would present impossible boundary problems. Studying the transmission of figures and theories of conspiracy in the genre fiction of the nineteenth century is nonetheless valuable, for it illustrates how historical contexts informed conspiracist interpretations of dangers, which then acquired narrative forms in the rapidly changing print media by which they were transmitted to an expanding reading public. I focus here on two generic clusters: Narratives of invasion (which prepared the ground for espionage fiction) and detective stories (which inherited material from sensation novels).

\section{Conspiracy and suspicion in the nineteenth century}

The meaning of 'conspiracy' changed in the nineteenth century. Albert Pionke informs our understanding of the term's usage in his analysis of the use of conspiracy as a legally effective term that government institutions in the Victorian period could resort to in order to discredit and prosecute dissident political movements (2004). This understanding of conspiracy as a legal concept and instrument for the consolidation of political constituencies echoes the first wave of conspiracy studies, for instance Richard Hofstadter's essay on 'The Paranoid Style of American Politics' (1966 [1964]), which referred to the circulation of conspiracist beliefs in nineteenthcentury American history, and David Brion Davis's thematic studies of political conspiracy theories (Hofstadter 1966; Davis 1969, 1972).

More recent examination of conspiracy in the nineteenth century has paid attention to its figuration in the fiction of the period. Theodore Ziolkowski surveys the persistence of secret society novels in the nineteenth century (2013). Alex J. Beringer studies the figure of conspiracy in American literature and is alert to its creative capacity to organise anxieties into narrative form. In the works he studies from the fin de siècle, "the term "conspiracy" did not simply describe a crime but became a vehicle through which dark suspicions about modernization and industrialization were channelled into exhilarating sensations of romance and mystery' (2012: 37). Adrian Wisnicki narrows the focus in his monograph on Conspiracy, Revolution, and Terrorism from Victorian Fiction to the Modern Novel to 'the conspiracy theory narrative', which is to say narratives that feature conspiracy theorising, whether as an expression of an emergent 'desire to know' (operative in Dickens, for instance) or to satirise a type of social anxiety (in G.K. Chesterton's The Man who was Thursday). This desire appeared as a diagnosable illness in the emergent science of psychology and as the formalisation of anxieties about dangers from abroad (Wisnicki 2008).

Luc Boltanski notices the contemporaneity, in the late nineteenth century, of detective fiction with the first instances of 'paranoia' as a psychiatric condition defined by Emil Kraepelin in 1899 and observes that ' $\mathrm{t}$ ] he investigator in a detective story thus acts like a person with paranoia, the difference being that he is healthy' (2014: 15). Much earlier and without this diagnostic terminology, Edgar Allan Poe wove into his 'little stalking narrative' (Rachman 1997: 656) a type of illness whose symptoms are nervousness and hyper-observation. The narrator of Poe's 'The Man of the Crowd' (1840) describes himself as recovering from illness, 'in one of those happy moods ..., when the film from the mental vision departs ... and the intellect, electrified, 
surpasses as greatly its everyday condition' (2008: 84). He becomes so compulsively fascinated by one man in particular that he follows him through the city for an entire night and day. The 'paranoid' narrator is both a proto-detective, and a proto-conspiracy theorist, in the way he fabulates various criminal lives of his subject before giving up and reflecting on the resistance of some mysteries to penetration. Eugene Sue also explored the criminal underground of Paris in the 1840s, in Les Mystères de Paris (1842-1843), in which detection is again a pretext for plots that involve the mysteries of social mobility in the modern, impenetrable city.

The earlier elements of the conspiracist imagination find their way into other genres in our own contemporary culture, which seems appropriate for a complex of ideas to which infiltration is such a crucial mode of transmission. In Simon Sellars's recent novel of academic failure and readerly derangement, the narrator 'Simon Sellars' is unravelling (in both senses) the psychopathologies that traverse the boundaries of his own and the world's mental health in a doomed doctoral thesis on J.G. Ballard:

My mission was to track what I considered to be Ballard's transdisciplinary mutant word virus, a mysterious code that could not be readily distilled into biography or literary theory. I wanted to analyse how that virus absorbs other cultural forces and the way other cultural forces absorb it and, in so doing, to arrive at a preliminary understanding of the dark forces that shape our lives.

(2018: 289)

Sellars's book is a case study in contemporary anxieties and provides a model for thinking about the transmission of conspiracy-mindedness across literary genres of the nineteenth century. 'Trans-disciplinary word virus' is an excellent description of how conspiracy, thought of as a narrative arrangement of material, moved in the nineteenth century (and still does) through and across media environments, dropping hints of insidious plots that might just be real and inviting a readership to adopt a suspicious perspective, tuned to alertness and a distrust of surface appearances.

Luc Boltanski argues for a connection between the modern academic disciplines and nineteenth-century genre fiction, and links detective and espionage fiction to how sociology 'challenges apparent reality and seeks to reach a reality that is more hidden, more profound and more real' (2014: 30). His is one of several arguments that the emergence of conspiracies corresponds to the rise of modern societies (see also Koselleck 1988). Rita Felski diagnoses literary and critical theory's determination to penetrate false appearances as the institutionalisation of suspicion in academic practices; of particular influence has been the engagement of literary critics (new historicists especially) with nineteenth-century literature, notably the realist novel, which is 'charged with fraudulence and fabrication, with masking social contradictions by pulling the wool over the reader's eyes' (2015: 95). In these many ways, the nineteenth century produced the modern, suspicious reader.

\section{The spectre of invasion}

Narratives of invasion conspiracies in the late-century looked suspiciously across the channel to Britain's European neighbours and remembered the prospect of invasion from earlier in the century. Napoleon Bonaparte's military adventures in continental Europe were hardly secretive or conspiratorial, but the fact that his troops never made landfall on British soil meant that his presence in the public imagination was volatile and malleable into exaggerated narratives. As Linda Colley writes, Napoleon was a spectral figure to the British and provided 'a chance for 
fantasy and wishful thinking, an opportunity for drama' (1994: 308). The French émigré population in the southeast of England mounted a personalised print campaign against him, amplifying and inventing a litany of his monstrous crimes into what is referred to as the 'Black Legend' (Semmel 2000). Natalie Petiteau's summary of the character attributed to him is telling, for it prefigures Richard Hofstadter's characterisation of the arch-conspirator. Napoleon was said to be 'a deserter, superstitious without Christian faith, violent, cynical, ambitious, unprincipled, puerile, cruel, sadistic, coarse, a charlatan without spirit, jealous, ingrate, unstable, untrustworthy' (Petiteau 1999: 32, my translation); Hofstadter's notional enemy of the people was, similarly, thought of as 'a perfect model of malice, a kind of amoral superman: sinister, ubiquitous, powerful, cruel, sensual, luxury-loving' (Hofstadter 1966: 32). The Napoleonic danger was painted in much the same anti-monarchical brush-strokes that had been applied earlier to secret societies and are repeated today when a political group is to be smeared as morally degenerate (Önnerfors 2018). Infiltration was also thought to be already underway, with French agents already placed to assist an attack and an English radical faction that would welcome the new political order. The coordination of these narrative elements of foreign military threat and domestic subversion were assembled later in the century into the popular format of future war or (invasion) fiction.

Invasion fiction flourished between very precise dates in the late nineteenth and early twentieth centuries. Despite a few precursors and a revival of the genre after the First World War, its major phase began in 1871 with George T. Chesney's story 'The Battle of Dorking' and came to an end when the outbreak of war in 1914 made its prophecies temporarily redundant. It would be a stretch to describe Chesney's story as a conspiracy theory; he was responding to the Prussian army's recent decisive victory over the French army and used the format (an account of successful invasion in the near future) to draw attention from this future perspective to bear on what he saw as Britain's military and cultural complacency: 'For us in England it came too late. And yet we have plenty of warnings, if we had only made use of them' (1871: 532). Even so, Chesney adopted the distinctive time-stamp of the conspiracy narrative, which Hofstadter summarises when he writes that the conspiracy theorist is always convinced that 'he lives at a turning point' (1966: 30). The conspiracy theory consistently calls for measures to be taken in the present to counteract forces that, while still latent, threaten the immediate future of the social order - or, in the case of invasion fiction, the nation-state.

The story provoked so much discussion that its formula was rapidly copied and taken up in following years (see Clarke 1992). The incorporation of the format into serial publication in the 'new journalism' of the period deserves particular attention. Here, its narratives were aligned with the serial rhythms of publications such as the Daily Mail and Pearson's Weekly, where the presentation of the invasion fiction copied the format of news reportage. Much like its contemporary utopian (and dystopian) fiction, this genre was news from the near-future and its formulaic qualities (Matin 2011: 804) only served to underscore the plausibility of the danger in readers' minds. One example was The Invasion of 1910 (1906), a tale of German invasion published in the Daily Mail. Its author, William Le Queux, cultivated the belief that he did, in fact, have intelligence of German military plans, which by disseminating in the guise of a fictional narrative, he effectively pre-empted (Sladen 1938: 136). A similar conceit is presented in the preface of the better known novel by Erskine Childers, The Riddle of the Sands (1903), in which the trappings of entertaining fiction are said to be deployed in order to alert as wide a readership as possible to the real threat of German invasion (2009 [1903]: xiii-ix). ${ }^{1}$ The conspiracist nature of invasion fiction lies not only in the existence of hostile plotters, but in the genre's implied or explicit claims to be a realistic description of an imminent, if still-latent, danger that the government could only struggle to rebut. How do you prove a negative, once it has taken hold and 
offers the allure of dissident belief? John Attridge says of espionage fiction that it 'titillates a hidden counterhistory of public events' (Attridge 2013: 132). The conspiracy theory, likewise, combines popular culture with historical revisionism.

An engineering project that prompted conspiracist thinking was the proposal in 1882 of a tunnel to be built under the channel, linking England and France. The project became the subject of a spate of invasion novels that took this vulnerability as their pretext, several of which imagined that many of the French emigrés living in southeast England (the enemy within) would collaborate with their compatriots. These anxieties were not restricted to popular fiction: James Knowles, editor of the Nineteenth Century, petitioned against the tunnel in 1882 citing security risks. Signatories to his letter included Robert Browning, Alfred Tennyson, T.H. Huxley, Cardinal Newman, Herbert Spencer, the Archbishop of Canterbury, several journal editors, five dukes, ten earls, 26 M.P.s, 17 admirals, 59 generals and many more (Clarke 1992: 96). There was no such panic in France, so these scenarios probably reflected then (as now) an island mentality to free movement of people, who were supposed to be in some kind of hostile collaboration against British interests.

The principal enemies of Britain in these narratives published between 1871 and 1914 were the Prussians, then France and Russia, then Germany, the Ottoman Turks and, in some cases, China. Some invasion fictions adopted a more global perspective and used the format to make claims about the security of the Empire as a whole. M.P. Shiel's unpleasant novel, The Yellow Danger (1898), was one such narrative, which imagined a malevolent Chinese plot to bring down the British Empire. Consistent with Victorian race characterisation, the Chinese strategy is underhand and manipulative, and more effective even than the British concerns of 'a conspiracy of the three great Continental Powers to oust England from predominance in the East' (Shiel 1898: 2). The destruction of the West is achieved by orchestrating the antagonism of the European powers: Ceding Chinese territories to France and offering control of the protectorate of the Yangtse River (traditionally a British power base) to Russia. China then strikes an economic blow by defaulting on its debts to England. In this complex, racist novel, the central villain who executes these plans is portrayed as a miscegenated cosmopolitan (despite Shiel's own creole identity) with 'a brown, and dark, and specially dirty shade in the yellow tan of his skin' (Shiel: 4). It is precisely his fluency in the ways of the West (after an education in Germany and professional experience in America) that makes him so dangerous. 'No European could be more familiar with the minutiae of Western civilization' (Shiel: 5). The consequences of globalisation generated the idea of a threat that Britain was insufficiently alert to, an anxiety that was in keeping with late-century concerns that world power would soon be ceded by the Anglo-Saxon powers (Bell 2011). In its imagination of foreign danger as a coordinated plan for racial replacement, the invasion fiction resembled conspiracy theories of the present day.

Yumna Siddiqi is one of the few literary critics to consider the imperial dimension of domestic crime fiction in Britain. She reads the (proto-)detective and espionage stories of Wilkie Collins, Arthur Conan Doyle and John Buchan as indicative of doubts regarding the security of the imperial project, pointing out for instance that around 12 of the Sherlock Holmes stories, while set in England, narrate the consequences of crimes or mysteries that have been committed 'in the extra-national space of Empire' (2008: 40). Detective fiction requires a pre-history; its invitation to the reader is to solve 'the problem of the omitted beginning' (Bloch 1996: 51). That beginning must be outside the narrative frame, and in an imperial framework may even be outside a national setting. Stephen Arata's study of Fictions of Loss in the Victorian Fin de Siècle (1996) was influential for its placement of apparently diverse genres - late gothic, detective, espionage - in the same late-imperial frame. Invasion fiction, like detective fiction, requires a pre-history, and one that is geographically, politically 
remote. Like the conspiracy theory, it reverses the chronology of the detective story in its anticipation of a crime not yet committed.

The print context of invasion fiction is underexamined and informs the transmission of the genre as well as its relation to the idea of conspiracy. Many of these stories were serialised in weekly and daily publications. Cyril Arthur Pearson and Alfred Harmsworth both successfully adopted and adapted the formula early in their careers, employing authors who were also journalists (for instance George Griffith, William Le Queux, M.P. Shiel, Louis Tracy). They presented the threat of invasion as a foreign conspiracy and made espionage crucial to their narrative elaboration, and also established journalists and editors in the stories as professionals who were ideally placed to detect invasion plots. This is particularly evident in The Spies of the Wight (1899), a novel by Francis Edward Grainger and published under the pen name Headon Hill in the weekly Black and White magazine. In the opening chapter, the journalist Monckton is summoned to receive his assignment (to surveil the treacherous Baron Von Holtzman). His editor, Wreford, is equipped through his web of connections across the worlds of international politics, finance and the criminal underworld to root out and expose Britain's enemies amid the sublime complexities of modern life.

Some looked back at the First World War and attributed responsibility in part to the jingoistic journalism of the fin de siècle. Assessing the causes of the First World War in the 1930s, Caroline Playne identified the Harmsworth press in particular for the feverish inflation of the threat of other European powers and 'the creation and nurture of the mental folly and nervous fears which helped set the world on fire in 1914' (1928: 112). Holbrook Jackson referred to the pre-war period's 'strangely inorganic patriotism' in 1913 (1976: 54) - a phrase that catches equally well our contemporary anxieties that patriotism is instrumentalised in media as an affective foundation for conspiracy beliefs about infiltration from abroad. Comparable claims about the distorting power of journalism had been made before: Suggestions regarding the effects of overheated writing on suggestible audiences went back to at least the 1820s, for instance in Henry Stebbing's (unsigned) description of the modern press in the Athenaum as 'one of the most extensively mischievous engines that can be placed in the hands of the shallow thinker, the mercenary speculator, or the false theorist' (1828: 273, emphasis added).

The language describes current opinions of the Internet as a breeding ground for conspiracy beliefs. It is only a little surprising, then, to encounter a conspiracy theory from the early nineteenth century that is just as outlandish as contemporary claims that there has been a cover-up to conceal the facts that the Earth is flat or that Greenland does not exist. Richard Whately, a polymath and later Archbishop of Dublin, responded to the unreality of Napoleonic representation in the British press (and the extraordinary drama of his career) to argue in 1819 that he could only be an invention of British newspaper editors, dreamed up to sell papers. Like a denier of the moon landings, he itemises the many unrealities of his reported exploits (for instance, the absurdly dramatic story of his escape from Elba and whirlwind recapture of most of Europe in the 100 days prior to Waterloo), and blames general credulity on that fact that ' $[\mathrm{m}]$ ost persons would refer to the newspapers as the authority from which their knowledge on the subject was derived' (1852: 15, original emphasis). He even reports a first-hand account of Moscow intact long after it was meant to have burned down.

Whately's argument is in fact ironic, intended both as a satire upon David Hume's argument against the historical truth of Jesus' miracles in An Enquiry Concerning Human Understanding (1748) and more pointedly against the excesses of British print media (Carver 2017). Its interest in historians of conspiracy culture is therefore in its deployment of humour in the presentation of a conspiracy theory, and as a counterexample to the historical claim that conspiracy narratives circulated first only among credulous readers/listeners, and only later acquired an ironic, playful dimension. 


\section{Networks (of detection)}

The modernisation of conspiracy narratives in the nineteenth century can be viewed in light of new technologies that facilitated new networks of association and communication, as well as the detective methods employed to identify them. The rapidity with which dynamite became a dramatic feature in popular fiction of anarchist plotting in the 1860s is a case in point (Wisnicki 2008: 143). To simply observe the rapid adoption of new technology into conspiracist plots is only to get half of the picture, however.

Two genres that introduced conspiracist elements into their narratives were sensation and detective fiction, both of which encouraged readers to recognise the susceptibility of modern communications networks for dissident and criminal activity. E.P. Thompson in The Making of the English Working Class draws a rich picture of the reliance of radical association on the anonymity of the postal service and the subterfuge employed in the interception and maintenance of this communications infrastructure (1980). The London Corresponding Society was founded in 1792 with the aim of disseminating progressive pamphlets and allowing dissident groups around Britain to be in contact with each other and the outside world. Thompson is especially sensitive to the attempts by spies to infiltrate these networks, and the methods of forgery and provocation by which they hyperbolised the coherence and intent of these networks in their written reports.

However real these subversive activities were, the figure of conspiracy that was attached to them was nonetheless the result of writing and at least partly confected description (Thompson 1980: 529). This repeats the creative process by which the exaggerated conspiratorial activities of the Illuminati circulated in written descriptions even after the group had disbanded. (For a detailed discussion of the development of the Illuminati conspiracy theories, see Chapter 4.2.) These societies had demanding writing requirements as conditions of membership and advancement, for instance the extensive reports and confessions that were required of the brethren (Koselleck 1988: 78-9).

The infrastructure of communications was likewise put to use in the plots of narrative fiction, where the potential for uneven distribution of knowledge could be made use of in literature that was realist inasmuch as it was set in a world bearing significant resemblance to the reader's own. The conspiracist character of the plots of invasion, detective and sensation fiction was not only the reflection of pressing contemporary anxieties, transmitted through the print culture where the new genre fiction was so successfully published. Conspiracy also served as what Anna Kornbluh, in her discussion of realism and the Psychic Economies in Victorian Form, calls a 'structuring metaphor ... of the sort uniquely afforded by literature' (2014: 11). Conspiracy articulated the figures of invasion and network and attached itself to contemporary practices of writing. In doing so, it incorporated the infrastructure of modern communications as the basis for establishing the asymmetries of information - secrets and lies - that were and are necessary conditions for the transposition of conspiracy into narrative form.

Letters were a system for conspiracist association that became a structural feature in the criminal plots of novels. The use of letters in sensation fiction, a genre whose distinguishing feature was 'the element of mystery' (Brantlinger 1982: 2), united the excitement of intrigue with epistolary networks. The function of letters in sensation fiction can be revelatory of characters' true intentions, inscribing the separation of surface appearance and hidden reality, the quality that Boltanski (2014) saw as common to detective fiction and sociology. In Wilkie Collins's novel Armadale (1864-1866), the criminal intentions of the principal villain (Lydia Gwilt) are only made plain to the reader in the first chapter ('Lurking Mischief') of Book 2, when private correspondence between the two plotters, Lydia Gwilt and Mrs Oldershaw, is 'leaked' to the 
reader (Collins 1995). As Laura Rotunno notes, letters regularly indicate guilt in sensation fiction, and also serve as exonerating evidence of the falsely accused (2013: 24). Handwriting can also constitute a clue for the detective, as with Lady Audley's Secret (1862), in which Robert Audley, a proto-detective, performs early graphological analysis on a letter written by the woman he suspects of criminality.

The effectiveness of Sherlock Holmes's analysis of written communication later in the century continues the apparent consistency of new, scientific methods of detection between criminal science and fiction. "He is the reader perfectly suited to the late-century innovations. Holmes is an expert in reading the postmark, the length of the telegram, the syntax of the postcard, the weight of the stationery, and the slant of the handwriting' (Rotunno 2013: 121). Holmes's techniques were influential on the developing methods of criminology at the end of the century (Truzzi 1983: 198). Graphology was a science promoted beyond its level of competency, however, and one notorious instance of its application illustrates its role in falsely generating the 'evidence' of a conspiracy and thus enabling a secondary conspiracy of its own. ${ }^{2}$ Alphonse Bertillon developed 'anthropometry', which was adopted by the French police prior to fingerprinting as a system for recording the biometric details of criminals and suspects: Cranial dimensions, relative finger lengths, photographic templates. His apparent success in identifying repeat offenders even though they assumed false identities led to the institution of anthropometric laboratories in several countries in the 1890s and influenced Francis Galton's research into eugenics (Csiszar 2013: 446). His elevation in the Paris Prefecture de Police led to his appearance as an expert graphologist in 1894 and 1899 in the case against Alfred Dreyfus for conspiring to betray France. His evidence assisted the wrongful conviction of Dreyfus, which was overturned in 1906.

The framing of criminality in conspiracist terms in the later nineteenth century had a wider social range than the fear of the urban underclass outbreeding the middle classes (the conspiracist dimension of social Darwinism). The anarchists were dangerous and distinctive because of the social verticality of their organisations. Representations of anarchist conspiracy drew on two axes of mobility: Plots that circulated underground and invisibly in the city's infrastructure, and the enthusiastic commitment to social disorder from within the refined upper classes.

In H.G. Wells's story 'The Stolen Bacillus', published in the Pall Mall Gazette in 1894, an anarchist steals what he thinks is a sample of cholera from a bacteriologist, who indulges in a flight of fancy as he holds up the sample to the would-be poisoner of the city:

Only break such a little tube as this into a supply of drinking-water, say to these minute particles of life that one must needs stain and examine with the highest powers of the microscope even to see, and that one can neither smell nor taste - say to them, 'Go forth, increase and multiply, and replenish the cisterns', and death - mysterious, untraceable death, death swift and terrible, death full of pain and indignity - would be released upon this city, and go hither and thither seeking his victims.

(1965 [1894]: 196)

The passage recapitulates so many elements of the conspiracy narrative in this period. There is the anarchist, committed to the violent subversion of society by secretive means. The bacillus is his ideal weapon for it operates along the very same pathways as he does: Underground, through the infrastructure of the modern city, with the purposes of infection and breakdown rather than sanitation and order. Anarchists and Fenians were both making use of dynamite at this time, and of the tunnels beneath the city to undermine their target buildings - a risk that led to the swearing in of sewer workers as Special Constables (Hwang 2013: 168). The anarchist dismisses his 
fellow terrorists as 'fools, blind fools - to use bombs when this kind of thing is attainable' (Wells 1965: 197). The introduction of infection through the city's waterworks is, effectively, a hack of modern systems intended to optimise urban health, but which also expose it to risk. The same is true of the anarchist's other methods: He has forged a letter of introduction to gain access to these deadly pathogens and believes himself to be 'a human vector', in the biopolitics of the city, making life an instrument of death (Fifield 2019: 36). With spoiler alerts and apologies, the narrative is cautionary, not catastrophic: The anarchist has stolen a harmless sample, whose only effect is to turn anyone who consumes it - the anarchist - blue.

Representation of terrorist plots in British nineteenth-century fiction involved socially indeterminate figures and association between members of classes normally kept apart. Take Hyacinth Robinson, the hapless protagonist in The Princess Casamassima (1885-1886), Henry James's novel of bohemian anarchism in London. Hyacinth is the son of mixed nationalities and reputation: His mother (French, disreputable, volatile) has murdered his supposed father (English, a Lord, also wayward) for breaking off their affair and dies in prison. Orphaned to a seamstress, Hyacinth grows up in poverty but with romantic ideas of his own social value inculcated by his foster parent. His involvement in the plotting begins with a friendship with a musician, through whose connections he enters his trade as a bookbinder, where he encounters French former communards, by whom he is introduced to an assistant chemist, who is an anarchist radical, and then via a retired army captain to the titular princess. The working classes he believes himself willing to sacrifice his life for 'excite his disgust' (James 1987: 160). The ideal anarchist crosses social worlds even if he or she cannot belong properly in any one of them.

In The Secret Agent (1907), by Joseph Conrad, the social range is again very broad, moving rapidly between a consulate, the chief of police and a pornographer in east London. Conrad's story from the previous year, 'The Informer' (1906), differs in that its master-conspirator is socially elevated enough to alarm the narrator by having excellent taste but no loyalty to the class for whom such taste is normally a distinction. "He was alive and a European; he had the manner of good society, wore a coat and hat like mine, and had pretty near the same taste in cooking. It was too frightful to think of (Conrad 1974: 76). The authors of sensation novels also arrayed conspiratorial forces of disorder against the comforting stabilities of the class system. In both Armadale and Lady Audley's Secret, the threats take the form of that socially indeterminate figure of the governess who insinuates her way into relationships above her acknowledged or pretended social status.

Sensation fiction agitated the patrician critics, not least because it seemed a kind of literature that might train suggestible readers to perceive conspiracies all around them. Ignatius Donnelly, one critic argues, wrote Caesar's Column (1890) in order to train readers to do exactly this: Discover clues to conspiracies in the real world (Beringer 2012: 53). This paranoid sensitivity was the concern of one reviewer of Lady Audley's Secret, who was representative of the pearlclutching alarm that the genre provoked in the reputable quarterlies:

The man who shook our hand with a hearty English grasp half an hour ago - the woman whose beauty and grace were the charm of last night, and whose gentle words sent us home better pleased with the world and with ourselves - how exciting to think that under these pleasing outsides may be concealed some demon in human shape, a Count Fosco or a Lady Audley! He may have assumed all that heartiness to conceal some dark plot against our life or honour, or against the life or honour of one yet dearer: she may have left that gay scene to muffle herself in a thick veil and steal to a midnight meeting with some villainous accomplice.

(Henry Longueville Mansel [unsigned] 1863: 489) 
The conspiracy form thus mediated the experiences and perception of fiction and life, and the normalisation of this paranoia occurred in the literary culture of the late nineteenth century, in newly consolidated literary genres that engaged the reader's suspicions, and his or her willingness to become a suspicious reader of genre fiction and of the real world.

\section{Conclusion}

One of the causes that Peter Knight suggests for the proliferation of conspiracy culture in the American 1960s is the recognition of an increasingly interconnected world (2001). The Cold War had divided the world into power blocs; modern telecommunications fed images from all corners of the world map to an ever-expanding audience; Rachel Carson's book, Silent Spring (1962), was indicative of an emergent insistence on the world as a single complex system and a mode of scientific discovery that pieced together information from different disciplines into a unified theory - in this way, too, comparable with the conspiracy theory. A recent review of her selected writings quotes her correspondence with a Connecticut doctor, in which she writes: 'Recently some of my thinking on all this has begun to fit together like the pieces of a jigsaw puzzle ... a great light is breaking in my mind' (Crist 2019: 3).

The similarities to a similar recognition of the world's webbiness in the nineteenth century are striking. As noted above, detective and invasion fiction registered an awareness that imperial systems could enable dangerous and hostile flows back to the seat of empire. These stories were published in the popular press alongside articles that described the daily routines - and the stranger happenings - of foreign lands; local and imperial news passed back and forth by ship and then by telegraph, a communications network that brought its visible technology into the urban centres. Richard Menke refers to Londoners' bemusement at the cables that were 'strung across the rooftops like a tangle of crazy knitting", citing Dickens's observation of the telegraph in All the Year Round, that 'its working is secret and bewildering to the average mind' (2008: 163). Dickens's article was published in 1859, the same year as the publication of Darwin's On the Origin of Species, which would infer from the geological record and the evidence of existing species that all life was bound together by a network of invisible lines of descent (Carver 2018). Darwin's speculations of entanglement recall Carson's discoveries of human and animal codependence, as well as Robert Langdon's sleuthing through the archives of past history.

The idea of foreign conspiracies to invade, absorbed into popular fiction, accustomed readers to plots that traversed countries and continents. Narrative representations of conspiracy have been internationalist since at least the time of secret societies' supposed involvement in the French Revolution, and this habit is now hard-wired into the genre, as with the high-speed journeys between European heritage sites and puzzle-solving in The Da Vinci Code (2003). Extreme cases are the Bond and Bourne films, to which a high number of city-breaks is an essential narrative feature. Both franchises lean heavily on the figure of the conspiracy - Spectre and the rogue U.S. intelligence agency respectively. These modern conspiracy thrillers' inheritance of detective and invasion fiction is most apparent in their principal structural difference: Jason Bourne's training makes him the ideal detective of a crime - his own - that has been committed in the past, while James Bond is tireless in his defence of the Western world from an attack that is always about to take place.

The absorption of conspiracy theories into narrative genres in the late nineteenth century even if a 'conspiracy fiction' genre was yet to come - relied on the infrastructure of this period. Anarchists could make use of scientific discoveries and turn these and the very machinery of the city against itself. Secret association adopted new technologies of communication, which became the fields of detective expertise, a competition between criminals and police in a specialised

1 
print environment that cultivated distinctive genres - for example, the Strand Magazine's successful run of Sherlock Holmes stories. Invasion fiction, published alongside news, was able to address readers as if the conspiracy were real, especially when these fictions made use of the realia of reportage. Nineteenth-century representations of conspiracy coalesced into genres that persist today, and did so in the modes of transmission that became available in the infrastructure of the modern city; dreams of infiltration acquired form in the process of their transmission.

\section{Notes}

1 The website of the same name, www.theriddleofthesands.com/, provides a wealth of resources on invasion and espionage fiction in the Victorian and Edwardian period.

2 This is the same ambiguity of conspiracy culture that Thompson identified in radical organisations and their infiltration much earlier.

\section{References}

Arata, S. (1996) Fictions of loss in the Victorian fin de siècle, Cambridge: Cambridge University Press.

Attridge, J. (2013) 'Two types of secret agency: Conrad, causation, and popular spy fiction', Texas Studies in Literature and Language, 55(2): 125-58.

Bell, D. (2011) The idea of greater Britain: empire and the future of world order, Princeton University Press.

Beringer, A.J. (2012) "“Some unsuspected author": Ignatius Donnelly and the conspiracy novel', Arizona Quarterly: A Journal of American Literature, Culture, and Theory, 68(4): 35-60.

Bloch, E. (1996) 'A philosophical view of the detective novel', in E. Bloch (ed.) The utopian function of art and literature: selected essays, trans. J. Zipes and F. Mecklenburg, Cambridge, MA: MIT Press, pp. 245-64.

Boltanski, L. (2014) Mysteries and conspiracies: detective stories, spy novels and the making of modern societies, 1st edn, Cambridge, UK: Polity Press.

Brantlinger, P. (1982) 'What is "sensational" about the "sensation novel"?' Nineteenth-Century Fiction, 37(1): 1-28.

Carver, B. (2017) Alternate histories and nineteenth-century literature: untimely meditations in Britain, France, and America, 1st edn, New York: Palgrave Macmillan.

Carver, B. (2018) 'An entangled forest: evolution and speculative fiction', Urbanomic. Available at: www. urbanomic.com/document/entangled-forest/. [Accessed 19 August 2019.]

Chesney, G.T. (1871) 'The battle of Dorking: reminiscences of a volunteer', Blackwood's Edinburgh Magazine, 109(667): 539-72.

Childers, E. (2009) The riddle of the rands, London: Atlantic Books.

Clarke, I.F. (1992) Voices prophesying war: future wars 1763-3749, 2nd edn, Oxford: Oxford University Press.

Colley, L. (1994) Britons: forging the nation, 1707-1837, London: Pimlico.

Collins, W. (1995) Armadale, ed. J. Sutherland, London: Penguin.

Conrad, J. (1974) A set of six, London: J.M. Dent and Sons Ltd.

Crist, M. (2019) 'A strange blight', London Review of Books, 41(11): 3-7.

Csiszar, A. (2013) 'Bibliography as anthropometry: dreaming scientific order at the fin de siècle', Library Trends, 62(2): 442-55.

Davis, D.B. (1969) The slave power conspiracy and the paranoid state, Baton Rouge: Louisiana State University Press.

Davis, D.B. (1972) The fear of conspiracy: images of un-American subversion from the revolution to the present, London: Cornell University Press.

Felski, R. (2015) The limits of critique, Chicago: University of Chicago Press.

Fifield, P. (2019) 'On the invisible threat: bacteriologists in fiction and periodical advertisements, 1894-1913', Journal of Victorian Culture, 24(1): 33-52.

Hill, H. (pseud.) (1899) The spies of the wight, London: C.A. Pearson.

Hofstadter, R. (1966) 'The paranoid style in American politics', in R. Hofstadter (ed.) The Paranoid Style in American Politics and Other Essays, London: Jonathan Cape, pp. 3-40.

Hwang, H. (2013) London's underground spaces: representing the Victorian city, 1840-1915, Edinburgh: Edinburgh University Press. 


\section{Ben Carver}

Jackson, H. (1976) The eighteen nineties: a review of art and ideas at the close of the nineteenth century, new illustrated edn, Hassocks: Harvester Press.

James, H. (1987) The princess Casamassima, Harmondsworth: Penguin.

Knight, P. (2001) Conspiracy culture: from the Kennedy assassination to the X-Files, London: Routledge.

Kornbluh, A. (2014) Realizing capital: financial and psychic economies in Victorian form, 1st edn, New York: Fordham University Press.

Koselleck, R. (1988) Critique and crisis: enlightenment and the pathogenesis of modern society, Oxford: Berg.

Le Queux, W. (1906) The invasion of 1910: with a full account of the siege of London, London: Eveleigh Nash.

Longueville Mansel, H. (1863) 'Sensation novels', Quarterly Review, 113(226): 481-514.

Matin, A.M. (2011) 'The creativity of war planners: armed forces professionals and the pre-1914 British invasion-scare genre', ELH, 78(4): 801-31.

Menke, R. (2008) Telegraphic realism: Victorian fiction and other information systems, Stanford, CA: Stanford University Press.

Önnerfors, A. (2018) 'Manichaean manipulation: Europe between apocalypse and redemption in the imaginary of the radical right', Centre for Analysis of the Radical Right. Available at: www.radicalright analysis.com/2018/05/15/manichaean-manipulation-europe-between-apocalypse-and-redemptionin-the-imaginary-of-the-radical-right/. [Accessed 19 August 2019.]

Petiteau, N. (1999) Napoléon, de la mythologie à l'histoire, Paris: Seuil.

Pionke, A.D. (2004) Plots of opportunity: representing conspiracy in Victorian England, Columbus: Ohio State University Press.

Playne, C.E. (1928) The pre-war mind in Britain: a historical review, London: Allen \& Unwin.

Poe, E A. (2008) Selected Tales, ed. D. van Leer, 2nd edn, Oxford: Oxford University Press.

Rachman, S. (1997) 'Reading cities: devotional seeing in the nineteenth century', American Literary History, 9(4): 653-75.

Rotunno, L. (2013) Postal plots in British fiction, 1840-1898, New York: Palgrave Macmillan.

Sellars, S. (2018) Applied ballardianism: memoir from a parallel universe, Falmouth: Urbanomic Media Ltd.

Semmel, S. (2000) 'British radicals and "legitimacy": Napoleon in the mirror of history', Past \& Present, 167: $140-75$.

Shiel, M.P. (1898) The yellow danger, London: Grant Richards. Available at: http://archive.org/details/ yellowdanger00shierich. [Accessed 19 August 2019.]

Siddiqi, Y. (2008) Anxieties of empire and the fiction of intrigue, Chichester: Columbia University Press.

Sladen, N. St. Barbe (1938) The real Le Queux: the official biography of William Le Queux, London: Nicholson \& Watson.

Stebbing, H. (1828) 'Unpublished lectures on periodical literature', in J. S. Buckingham (ed.) Athenaum, 18, London, UK: William Lewer, pp. 273-5.

Thompson, E.P. (1980) The making of the English working class, rev. edn, London: Penguin.

Truzzi, M. (1983) 'Sherlock Holmes: applied social psychologist' in U. Eco and T.A. Sebeok (eds.) The sign of three: Dupin, Holmes, Peirce, Bloomington: Indiana University Press, pp. 55-80.

Wells, H.G. (1965) The complete short stories of H. G. Wells, London: Ernest Benn Ltd.

Whately, R. (1852) Historic doubts relative to Napoleon Buonaparte, 11th edn, London: John W. Parker and Son.

Wisnicki, A.S. (2008) Conspiracy, revolution, and terrorism from Victorian fiction to the modern novel, London: Routledge.

Ziolkowski, T. (2013) Lure of the arcane: the literature of cult and conspiracy, Baltimore: Johns Hopkins University Press.

1 